\title{
Environmental Friendly Synthetic Modification of Amberlite XAD-2 Resin for the Removal of Highly Toxic Hexavalent Chromium from Water
}

\author{
Waqas Jamil, ${ }^{1,}{ }^{*}$ Zunaira Memon, ${ }^{1}$ Saima Qayyum Memon, ${ }^{2}$ \\ Muhammad Kashif Samon, ${ }^{3}$ Muhammad Taha ${ }^{4}$ and Khalid Mohammad Khan ${ }^{4,5}$ \\ ${ }^{1}$ Institute of Advanced Research Studies in Chemical Sciences, University of Sindh, Jamshoro, 76080, Pakistan \\ ${ }^{2}$ Dr. M. A. Kazi Institute of Chemistry, University of Sindh, Jamshoro, 76080, Pakistan \\ ${ }^{3}$ Centre for Pure and Applied Geology, University of Sindh, Jamshoro, 76080, Pakistan \\ ${ }^{4}$ Department of Clinical Pharmacy, Institute for Research and Medical Consultations (IRMC), \\ Imam Abdulrahman Bin Faisal University, P.O. Box 1982, Dammam, 31441, Saudi Arabiad, \\ ${ }^{5}$ H.E.J. Research Institute of Chemistry, International Center for Chemical and Biological Sciences, \\ University Karachi, Karachi 75270, Pakistan \\ *Corresponding author: E-mail:waqas.jamil@usindh.edu.pk,waqasjam2@yahoo.com \\ Tel. +923322324551
}

Received: 07-16-2019

\begin{abstract}
Amberlite XAD-2 functionalized by coupling through $-\mathrm{C}=\mathrm{N}$ - spacer with isatin via an environmental friendly protocol. The modified resin was used for the evaluation of its sorption capacity towards toxic $\mathrm{Cr}$ (VI) ions using spectrophotometer. $\mathrm{pH}$, volume, sorbent amount, initial concentration of $\mathrm{Cr}(\mathrm{VI})$ ions, and agitation time were optimized. The Freundlich and Dubinin- Radushkevich models gave better fit to isotherm data than Langmuir model. The evaluation of kinetic data indicated pseudo-first-order kinetics followed by sorption process. Thermodynamic parameters were also evaluated. Maximum recovery was obtained at $10 \mathrm{~mL}$ of $0.1 \mathrm{M} \mathrm{NaOH}$. Spiking methodology was used to confirm the validity of proposed method. The results revealed that developed method can be used for the removal of $\mathrm{Cr}(\mathrm{VI})$ ions efficiently from water, as well as reused for three cycles.
\end{abstract}

Keywords: Amberlite XAD-2; environmental Friendly; toxicity; chromium VI; isatin

\section{Introduction}

Heavy metals are continuously discharged into the natural environment. The rapid industrialization and their growth in the world pollution cause trouble to all forms of life. Most of the industries discharge wastewater and their effluents containing toxic metals without proper treatment and it becomes a major risk for human health. ${ }^{1-3}$

Chromium is a commonly used metal in various industries, such as chrome plating, leather tanning, dyes, and wood treatment. ${ }^{4}$ Chromium primarily occurs in two different oxidation states, i.e. trivalent [Cr (III)] and hexavalent chromium $[\mathrm{Cr}(\mathrm{VI})]$. $\mathrm{Cr}(\mathrm{III})$ is considered as a crucial trace mineral and it is essential for normal removal rates of glucose from blood, as well as protein and lipid metabolism, ${ }^{5}$ however $\mathrm{Cr}(\mathrm{VI})$ is a well-established carcinogen associated with lung, nasal and sinus cancer. It diffuses into the cell membrane of living organisms owing to its high solubility in water, high oxidation potential and relatively smaller size. ${ }^{6}$ The high levels of $\mathrm{Cr}$ (III) may have some adverse health effects, while $\mathrm{Cr}$ (VI) is hazardous even at low concentrations. The extensive use of chromium in the industries and improperly treated water effluent introduce environmental concerns. ${ }^{78}$ According to World Health Organization (WHO) and US Environmental Protection Agency (EPA), the permissible limit of $\mathrm{Cr}(\mathrm{VI})$ is 0.05 and $0.1 \mathrm{mg} / \mathrm{L}$ respectively in drinking water. ${ }^{9}$ The continuous elevation of $\mathrm{Cr}(\mathrm{VI})$ concentration is one of the prime cause of water toxicity, therefore the elimination of $\mathrm{Cr}(\mathrm{VI})$ toxic species from water resources is of current interest to researchers. 
Heavy metal ions can be removed from wastewater in order to reduce toxicity by using various methodologies including adsorption, biodegradation, ion exchange, oxidation, solvent extraction etc, ${ }^{10}$ as well as reduction process that converts $\mathrm{Cr}$ (VI) to $\mathrm{Cr}$ (III) has also reported for the remediation of waste water.

Among them, adsorption is the most common technique for the remediation of waste water from pollutants, due to its cost effectiveness and easy to handle. Adsorption technique has capacity for recovery of value added components via desorption and regeneration of adsorbent. ${ }^{11,12}$

Both natural as well as synthetic sorbents gained much attention owing to their metal-binding capacities, such as Alisma Plantago Aquata (APA), modified rice bran, coconut shell carbon, and banana pith etc has been reported as natural sorbents for the removal of $\mathrm{Cr}$ (III), $\mathrm{Cu}$ (II), $\mathrm{Zn}$ (II), Cd (II), Pb (II), and Rhodamine-B from water, ${ }^{13-16}$ while synthetic sorbents including new synthetic polymers and modified polymeric material like polystyrene and Amberlite XAD resins have been used to remove chemicals or metal ions from water and soil. ${ }^{17}$ Amberlite XAD-2 can be used as sorbent due to high surface area and large pore size, moreover it can be functionalized via mild techniques and these modifications make it more selective for the target analytes. ${ }^{18}$

\section{Experimental}

\section{1. Instruments}

Orion 5 star model pH meter was used to carry out pH measurements. Orbital Incubator Model I-4000 was used for batch experiments. Fourier Transform Infrared Spectroscopy (FT-IR) analysis in each step of synthesis i.e nitration, reduction and isatin based Amberlite XAD-2 resin was made with FT-IR model Nicolet IS10.

Scanning Electron Microscope (SEM) images for confirmation of morphological changes were carried out by using a scanning electron microscope Jeol model JSM6490 LV. Chromium as Cr(VI)-diphenyl carbazide complex was determined by Hitachi 220 Spectrophotometer.

\section{2. Reagents and Solutions}

The chemicals used to carried out the experimental work were chemically pure and of analytical grade.

Amberlite XAD-2, Concentrated (Conc.) hydrochloric acid ( $\mathrm{HCl})$, Conc. sulphuric acid $\left(\mathrm{H}_{2} \mathrm{SO}_{4}\right)$, Conc. nitric acid $\left(\mathrm{HNO}_{3}\right)$, sodium hydroxide $(\mathrm{NaOH})$, potassium chloride $(\mathrm{KCl})$, tin (II)chloride $\left(\mathrm{SnCl}_{2}\right)$, ethanol $\left(\mathrm{C}_{2} \mathrm{H}_{5} \mathrm{OH}\right)$, Isatin, sodium acetate $\left(\mathrm{CH}_{3} \mathrm{COONa}\right)$, acetic acid $\left(\mathrm{CH}_{3} \mathrm{COOH}\right)$, potassium dichromate $\left(\mathrm{K}_{2} \mathrm{Cr}_{2} \mathrm{O}_{7}\right)$, 1,5-diphenylcarbazide, acetone $\left[\left(\mathrm{CH}_{3}\right)_{2} \mathrm{CO}\right]$, sodium nitrate $\left(\mathrm{NaNO}_{3}\right)$, sodium phosphate $\left(\mathrm{Na}_{3} \mathrm{PO}_{4}\right)$, cobalt (II) acetate $\left[\mathrm{Co}\left(\mathrm{CH}_{3} \mathrm{COO}\right)_{2} \cdot 4 \mathrm{H}_{2} \mathrm{O}\right]$, Sodium Phosphate $\left(\mathrm{Na}_{3}\right.$ $\left.\mathrm{PO}_{4}\right)$, copper (II) chloride $\left(\mathrm{CuCl}_{2}\right)$, nickel (II) chloride
$\left(\mathrm{NiCl}_{2} \cdot 6 \mathrm{H}_{2} \mathrm{O}\right)$, manganese sulphate $\left(\mathrm{MnSO}_{4} \cdot \mathrm{H}_{2} \mathrm{O}\right)$, magnesium chloride $\left(\mathrm{MgCl}_{2}\right)$, Iron (III) Nitrate $\left[\mathrm{Fe}\left(\mathrm{NO}_{3}\right)_{3}\right]$, sodium carbonate $\left(\mathrm{Na}_{2} \mathrm{CO}_{3}\right)$ were purchased from Sigma-Aldrich and Merck (Germany).

The $\mathrm{pH}$ was adjusted by using desired buffer solutions of different ratios of $0.1 \mathrm{M} \mathrm{HCl} / \mathrm{KCl}$ for $\mathrm{pH} 2,0.2 \mathrm{M}$ $\mathrm{CH}_{3} \mathrm{COOH} / \mathrm{CH}_{3} \mathrm{COONa}$ for $\mathrm{pH} 4$ and 6 and $0.1 \mathrm{M} \mathrm{NaOH}$ for $\mathrm{pH} 8$ and 10. The $1000 \mathrm{ppm}$ stock solution of $\mathrm{Cr}(\mathrm{VI})$ was prepared by adding $0.2835 \mathrm{~g}$ of $\mathrm{K}_{2} \mathrm{Cr}_{2} \mathrm{O}_{7}$ in $100 \mathrm{~mL}$ distilled. Dilution method was used for the preparation of various $\mathrm{Cr}(\mathrm{VI})$ concentrations such as $100 \mathrm{ppm}, 10 \mathrm{ppm}, 8$ ppm, 6 ppm, 4 ppm and 2 ppm.

\section{3. Procedure of Synthetic Modification of Amberlite XAD-2 Resin}

Nitration and reduction of Amberlite XAD-2 Resin was done by reported procedure. ${ }^{19}$

In final modification step, $2 \mathrm{~g}$ of aminated resin was grinded with $2 \mathrm{~g}$ of isatin in the presence of catalytic amount of $\mathrm{HCl}(1 \mathrm{~mL})$ for $15 \mathrm{~min}$ in pestle mortar in order to provide appropriate mechanical energy for reaction. The camel brown precipitates were obtained, washed with water and ethanol and subjected for the IR spectroscopy.

\section{4. Sorption Procedure}

Sorption experiments were conducted through batch technique in an incubated shaker by varying the parameters that can affect sorption of $\mathrm{Cr}$ (VI) on to isatin based Amberlite XAD-2 resin. The effect of $\mathrm{pH}$, volume of sorbate, sorbent dosage, shaking time, temperature and initial concentration was studied. In this regard, $\mathrm{pH}$ was varied from 2 to 10 . The $\mathrm{pH}$ was adjusted by using buffer solutions of $0.1 \mathrm{M} \mathrm{HCl} / \mathrm{KCl}$ for $\mathrm{pH} 2,0.2 \mathrm{M} \mathrm{CH}_{3} \mathrm{COOH} / \mathrm{CH}_{3} \mathrm{COO}$ $\mathrm{Na}$ for $\mathrm{pH} 4$ and 6 and $0.1 \mathrm{M} \mathrm{NaOH}$ for $\mathrm{pH} 8$ and 10. Sorbate volume, resin amount, shaking time, temperature and initial concentration of potassium dichromate solution were optimized in range of $10-60 \mathrm{~mL}, 0.05$ to $0.35 \mathrm{~g}, 5$ to $320 \mathrm{~min}, 10$ to $50^{\circ} \mathrm{C}$ and 5 to 1000 ppm respectively. After the predetermined time, the sorbate solution was withdrawn and filtered to separate the sorbent. For spectrophotometric determination of $\mathrm{Cr}$ (VI) 1,5-diphenyl carbazide reagent was used, spectrophotometer was calibrated using $\mathrm{Cr}(\mathrm{VI})$ solution (2 to $10 \mathrm{ppm}$ ) contained $1 \mathrm{~mL}$ of 1,5-diphenyl carbazide and $2 \mathrm{~mL}$ of $3 \mathrm{M} \mathrm{H}_{2} \mathrm{SO}_{4}$. The concentration of metal ions before and after sorption was measured by following procedure.

$\%$ sorption was calculated using Eq. (1).

$$
\% \text { sorption }=\left(\frac{C_{\mathrm{i}}-C_{\mathrm{f}}}{C_{\mathrm{i}}}\right) \times 100
$$

Where $C_{i}$ and $C_{f}$ are the initial and final concentration of solution before and after sorption in $(\mathrm{mg} / \mathrm{L})$ of Cr(VI) respectively. 


\section{5. Desorption Experiment}

$0.25 \mathrm{~g}$ of used sorbent was agitated with 5 and $10 \mathrm{~mL}$ of $0.1 \mathrm{M} \mathrm{HCl}, 0.1 \mathrm{M} \mathrm{HNO}_{3}$ and $0.1 \mathrm{M} \mathrm{NaOH}$ respectively. The sorbent was collected from solution by filtration after the recovery experiment and washed with a plenty of distilled water and reused for analysis.

\section{Results and Discussion}

\section{1. Chemistry and FT-IR Analysis}

The synthetic modification was done by three steps i.e. Nitration followed by reduction and formation of isatin based Amberlite XAD-2 Fig. 1.

In last step of modification a solid state chemistry was used in order to make modification environmental benign. In this regard amino-Amberlite $\mathrm{XAD}-2$ was ground with isatin in the pestle mortar with different intervals of time i.e. 5, 10 and $15 \mathrm{~min}$. After each interval of time IR spectrum was taken to confirm the maximum conversion of amino group into imine group. The 15 min grinding was found to be enough for conversion. After $15 \mathrm{~min}$ sharp peaks for imine bond was observed with disappearance of amino group peaks Table-1. After 15 min grinding, camel brown precipitates were obtained. These precipitates were washed with distilled water as well as ethanol in order to remove impurities or un-reacted isatin.

Table 1. Grinding Time for Maximum Conversion

\begin{tabular}{cc}
\hline Grinding time (min) & Imine Peak Appearance \\
\hline 5 & Weak \\
10 & Medium \\
15 & Intense \\
\hline
\end{tabular}<smiles>CC(C)c1ccccc1</smiles><smiles>O=[N+]([O-])c1ccc(C(I)I)cc1</smiles>
$\underset{90 \mathrm{C}}{\stackrel{\mathrm{SnCl}_{2}+\mathrm{HCl}}{\longrightarrow}}$ $\mathrm{NO}_{2}$ (re

\section{Amberlite} XAD-2

\section{Nitro- Amberlite} XAD-2<smiles>CC(C)(C)c1ccc(N)cc1</smiles><smiles>O=C1Nc2ccccc2C1=O</smiles><smiles>O=C(Cl)C1CCCCC1</smiles>

Figure 1. Reaction Scheme for Synthetic Modification of Amberllite XAD-2
XAD-2

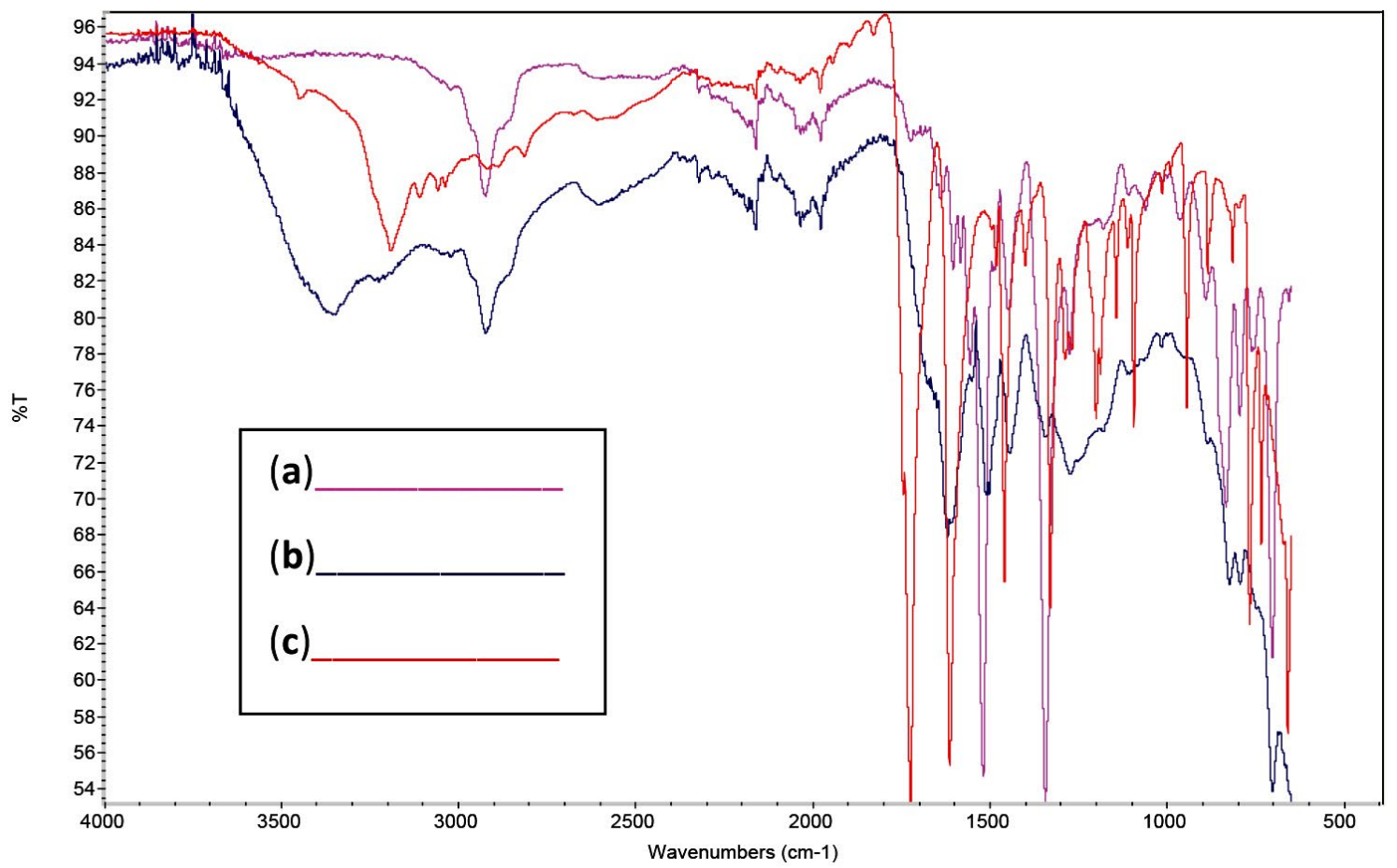

Figure 2. FT-IR Spectra of (a) Nitro-Amberlite XAD-2 (b) Amino- Amberlite XAD-2 (c) Isatin based Amberlite XAD-2 
All three products obtained from each step of synthesis were subjected to FT-IR. The presence of two clear peaks at 1519.65 and $1345.19 \mathrm{~cm}^{-1}$ which were assigned for $\mathrm{N}-\mathrm{O}$ asymmetric and $\mathrm{N}-\mathrm{O}$ symmetric stretching vibration respectively, confirmed that nitration of Amberlite XAD-2 has carried out successfully Fig. 2. (a). The reduction process i.e. conversion of nitro into amino group was confirmed by the presence of peaks at 3355.37, 1621.87 and $1272.53 \mathrm{~cm}^{-1}$, assigned for N-H stretching, N-H bending, C-N stretching respectively. Peaks for nitro group were disappeared, that confirmed the successful reduction Fig. 2. (b). The Isatin based Amberlite XAD- 2 product was confirmed by the prominent imine $(-\mathrm{C}=\mathrm{N}-)$ peak at $1614.68 \mathrm{~cm}^{-1}$, it also showed peak at $3189.40 \mathrm{~cm}^{-1}$ and $1725.41 \mathrm{~cm}^{-1}$ which are attributed to $\mathrm{N}-\mathrm{H}$ and $\mathrm{C}=\mathrm{O}$ of amide group of isatin respectively, shown in Fig. 2. (c) ${ }^{20,21}$

\section{2. SEM Analysis}

SEM analysis was carried out to examine the surface morphology of both modified and free Amberlite XAD-2 resin. Fig. 3. (a) is showing SEM photograph of free Amberlite XAD-2 resin and Fig. 3. (b) SEM photograph of Isatin based Amberlite XAD-2 resin. Surface modification of Amberlite XAD-2 is confirmed by significant difference in morphology which can be seen in images of free and modified Amberlite XAD-2 resin.

\section{3. pH Effect}

$\mathrm{pH}$ is considered as a key parameter which influences the surface activity of the resin for the sorption of metal ions. There was a slight increase in \% sorption from $\mathrm{pH} 2-4$. The removal of $\mathrm{Cr}(\mathrm{VI})$ was then reduced with rising $\mathrm{pH}$ which is shown in Fig. 4. The sorption of metals is associated to the surface functional groups and chemistry of the sorbate metal ion-solvent interaction that change with the $\mathrm{pH}$. The chromium (VI) ions can exist as hydrogen chromate $\left(\mathrm{HCrO}_{4}^{-}\right)$or chromate $\left(\mathrm{CrO}_{4}^{2-}\right)$ or dichromate $\left(\mathrm{Cr}_{2} \mathrm{O}_{7}{ }^{2-}\right)$ which depends

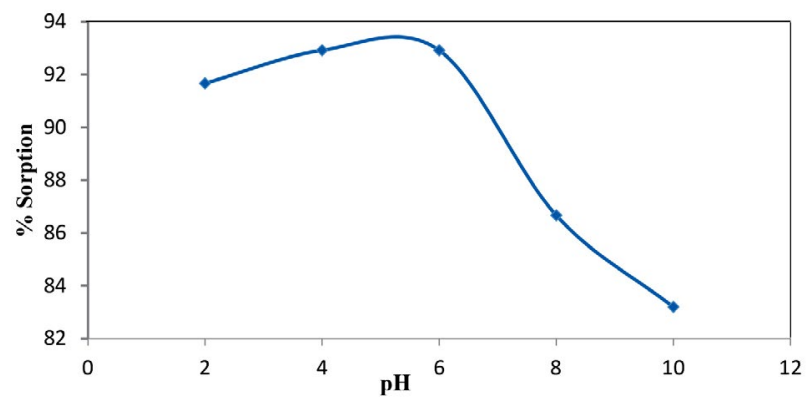

Figure 4. $\mathrm{pH}$ Effect for $\mathrm{Cr}(\mathrm{VI})$ sorption onto Isatin based Amberlite $\mathrm{XAD}-2$ resin

upon the $\mathrm{pH}$ of the solution. The dominant form of $\mathrm{Cr}(\mathrm{VI})$ is $\mathrm{HCrO}_{4}{ }^{-}$at acidic $\mathrm{pH}$ 2, and predominant forms at higher $\mathrm{pH}$ are $\mathrm{CrO}_{4}{ }^{2-}$ and $\mathrm{Cr}_{2} \mathrm{O}_{7}{ }^{2-}$. Due to strong electrostatic attraction between negatively charged chromium species and positively charged surface groups higher sorption at lower $\mathrm{pH}$ is observed and above $\mathrm{pH} 6$ sorption was reduced, which can be attributed to competitive sorption of $\mathrm{CrO}_{4}{ }^{2-}$ and $\mathrm{OH}^{-}$ions. ${ }^{22}$

\section{4. Volume Effect}

The volume effect of $\mathrm{Cr}(\mathrm{VI})$ on \%sorption by isatin based Amberlite XAD-2 was investigated and is shown in

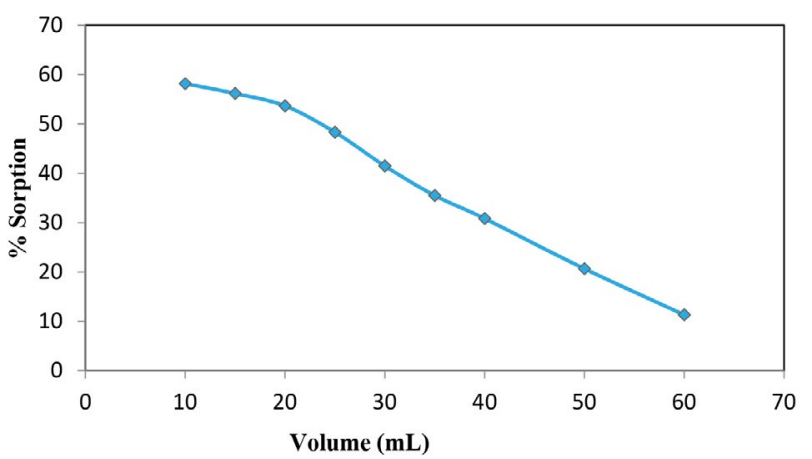

Figure 5. Volume effect for $\mathrm{Cr}(\mathrm{VI})$ sorption onto isatin based Amberlite XAD-2 resin
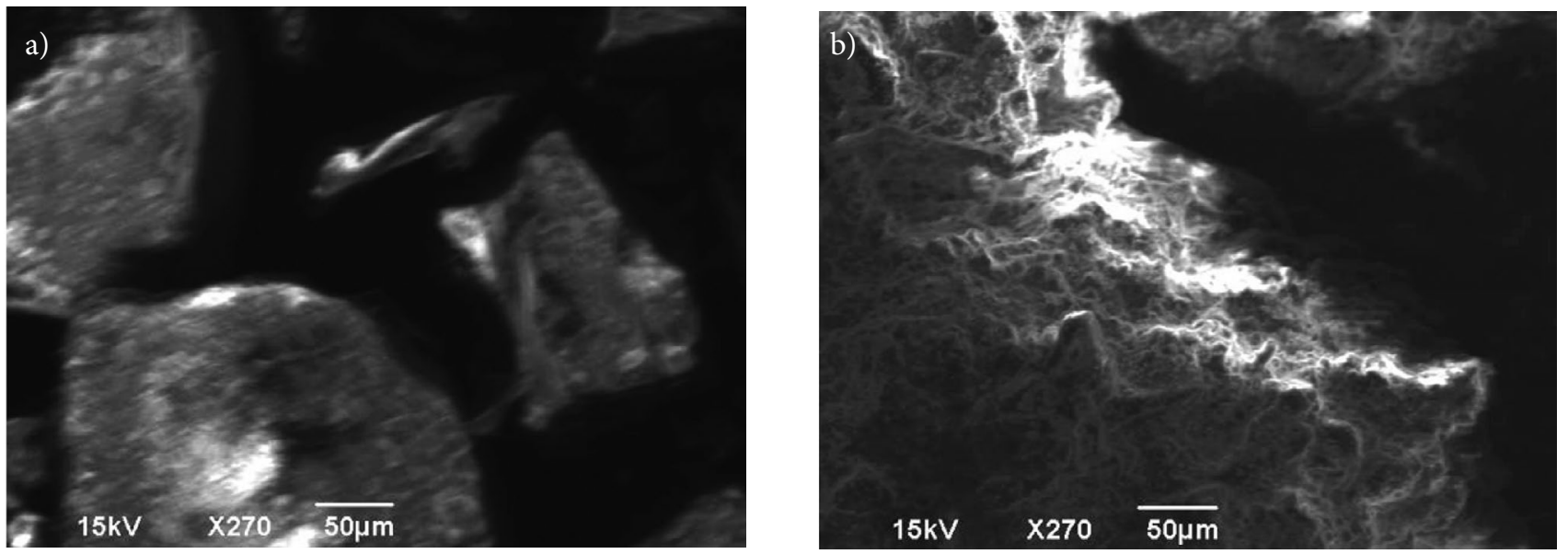

Figure 3. SEM photograph of (a) free Amberlite XAD-2, (b) Isatin based Amberlite XAD-2 
Fig. 5. Volume was varied from 10 to $60 \mathrm{~mL}$, maximum response was observed at $10 \mathrm{~mL}$, sorption was decreased with an increase in volume can be attributed to limited availability of sorption sites because $\mathrm{Cr}(\mathrm{VI})$ ions were amplified with increase in volume of $\mathrm{Cr}(\mathrm{VI})$ solution but resin amount was constant.

\section{5. Resin Dosage Effect}

The resin dosage effect on the sorption of $\mathrm{Cr}(\mathrm{VI})$ ions were examined in the range of $0.05 \mathrm{~g}$ to $0.35 \mathrm{~g}$, sorption was increased with increase in resin amount up to $0.25 \mathrm{~g}$, after which sorption capacity nearly remained constant shown in Fig. 6. Due to larger surface area and accessibility of more sorption sites, sorption was increased with resin amount. At higher sorbent dosage there are not enough $\mathrm{Cr}(\mathrm{VI})$ ions in the solution to occupy the active sites and as a result the sorption tends to become constant. So $0.25 \mathrm{~g}$ of modified Amberlite XAD-2 was chosen as most favorable resin amount for further analysis.

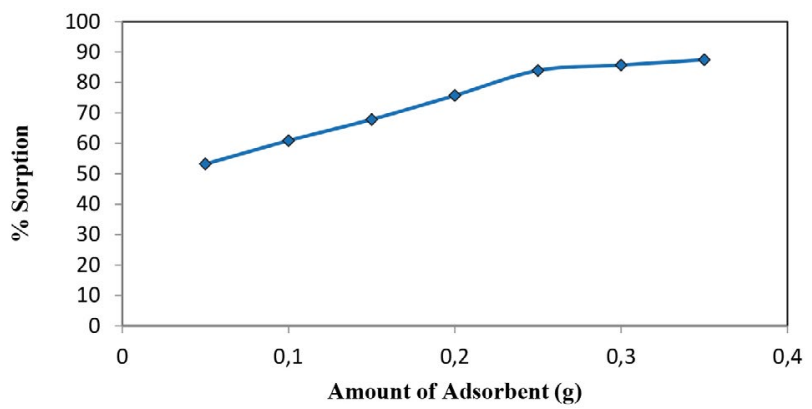

Figure 6. Resin dosage effect for $\mathrm{Cr}(\mathrm{VI})$ sorption

\section{6. Kinetic Study}

The influence of shaking time on \% sorption was examined by varying the time from 5 to $320 \mathrm{~min}$ by keeping other optimized parameters constant. It was observed that the sorption was increased till $60 \mathrm{~min}$, after 60 to $320 \mathrm{~min}$ no significant change in sorption was observed, and the system attained equilibrium. Kinetic models are of great importance for analyzing the kinetic data, they can give description of what is happening during the sorption process and can also give significant information about the sorbed and residual amount of solute in the solution at any instant of the experiment. ${ }^{23}$ The sorption mechanism was identified by subjecting the studied kinetic data to three most commonly used kinetic models, known as Lagergren, Ho and Mckay and Morris-Weber models.

\section{6. 1. Lagergren (Pseudo-First-Order Kinetics)}

Lagergren equation is given as;

$$
\ln \left(\mathrm{q}_{\mathrm{e}}-\mathrm{q}_{\mathrm{t}}\right)=\ln \mathrm{q}_{\mathrm{e}}-\mathrm{k}_{1 \mathrm{t}}
$$

Where $K_{1}$ is the rate constant of pseudo-first-order in $\left(\mathrm{min}^{-1}\right)$ and $\mathrm{q}_{\mathrm{e}}(\mu \mathrm{g} / \mathrm{g})$ is the the amount of $\mathrm{Cr}(\mathrm{VI})$ ions sorbed on the sorbent at equilibrium were determined from the slope and intercept of linear plot of $\ln \left(q_{e}-q_{t}\right) V s t$ shown in Fig. 7 and $\mathrm{q}_{\mathrm{t}}(\mu \mathrm{g} / \mathrm{g})$ is the amount of $\mathrm{Cr}(\mathrm{VI})$ ions sorbed on the sorbent at time t. ${ }^{24}$ Kinetic parameters which are obtained in this study of pseudo-first-order model are given in Table 2 .

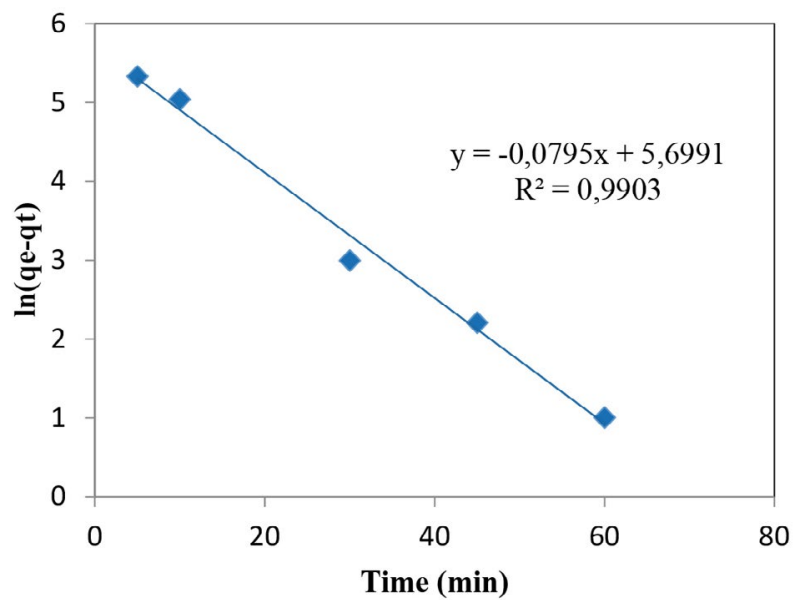

Figure 7. Lagergren kinetic model for $\mathrm{Cr}(\mathrm{VI})$ sorption onto isatin based Amberlite XAD-2

\section{6. 2. Ho and Mckay (Pseudo-Second-Order Kinetics)}

Ho and Mckay kinetic model is presumably depend on chemisorptions, in which sorption occur because of electron exchange between sorbate and sorbent. The pseudo-second-order rate equation is given as;

$$
\frac{t}{q_{\mathrm{t}}}=\left(\frac{t}{k_{2} \mathrm{q}_{\mathrm{e}}^{2}}\right)+\left(\frac{1}{q_{\mathrm{e}}}\right)
$$

Where, $\mathrm{K}_{2}$ is rate constant in $(\mathrm{g} / \mu \mathrm{g} \mathrm{min})$ of pseudo-second-order and $\mathrm{q}_{\mathrm{e}}(\mu \mathrm{g} / \mathrm{g})$ is the the amount of $\mathrm{Cr}(\mathrm{VI})$ ions sorbed on the sorbent at equilibrium were obtained from the slope and intercept of linear plot of $t / q_{t}$ against $t$

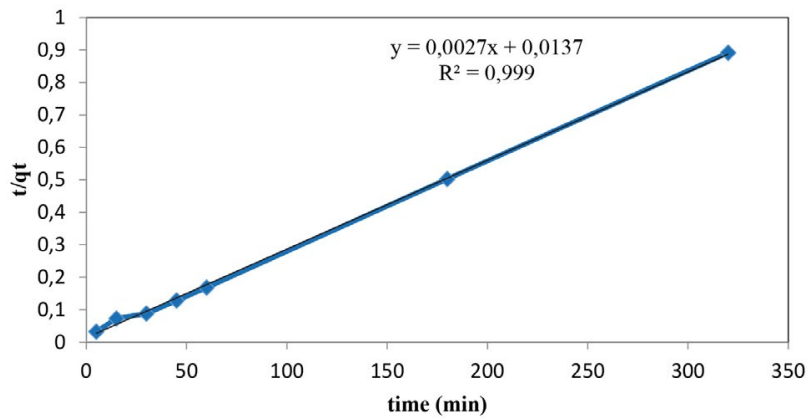

Figure 8. Ho and Mckay kinetic model for $\mathrm{Cr}(\mathrm{VI})$ sorption onto isatin based Amberlite XAD-2 
Table 2. Kinetic parameters for the $\mathrm{Cr}(\mathrm{VI})$ sorption onto isatin based Amberlite XAD-2 resin

\begin{tabular}{|c|c|c|c|c|c|c|c|}
\hline $\mathrm{K}_{1}\left(\min ^{-1}\right)$ & $\begin{array}{c}\text { Pseudo-first } \\
\text { qe }(\mu \mathrm{g} / \mathrm{g}) \\
\text { Calculated }\end{array}$ & $\begin{array}{l}\text { er kinetic model } \\
\text { qe }(\mu \mathrm{g} / \mathrm{g}) \\
\text { Experimental }\end{array}$ & $\mathbf{R}^{2}$ & $\mathrm{~K}_{2}(\mathrm{~g} / \mu \mathrm{g} \min )$ & $\begin{array}{l}\text { eudo-second } \\
\text { qe ( } \mu \mathrm{g} / \mathrm{g}) \\
\text { Calculated }\end{array}$ & $\begin{array}{c}\text { ler kinetic mode } \\
\text { qe }(\mu \mathrm{g} / \mathrm{g}) \\
\text { Experimental }\end{array}$ & $\mathbf{R}^{2}$ \\
\hline 0.079 & 298.5 & 357 & 0.990 & 0.013 & 76.92 & 357 & 0.999 \\
\hline
\end{tabular}

shown in Fig. 8 and $\mathrm{q}_{\mathrm{t}}$ in $(\mu \mathrm{g} / \mathrm{g})$ is the sorbate amount retained at time t. ${ }^{25}$ Kinetic parameters which are obtained in this study are given in Table 2.

Table 2. has summarized the pseudo-first-order and pseudo-second-order kinetic parameters which showed calculated qe value $298.5 \mu \mathrm{g} / \mathrm{g}$ of Lagergren is more close to experimental value as compared to calculated value of Ho and Mckay $76.92 \mu \mathrm{g} / \mathrm{g}$ which indicated that pseudo-first-order rate equation is more appropriate for explanation of kinetic process.

\section{6. 3. Morris-Weber Model (Intra-Particle Diffusion Model)}

The diffusion mechanism cannot be recognized only by Lagergren, Ho and Mckay kinetic models, therefore kinetic data was also applied to Morris-Weber model. This model states; if the plot of $\mathrm{q}_{\mathrm{t}}$ against $\sqrt{\mathrm{t}}_{\mathrm{t}}$ is straight and passing through origin then the sorption is considered to occur via intra-particle diffusion and the rate controlling step only depends upon it, while if it is not passing from the origin it gives the indication that at the same time some other kinetic phenomenon may be responsible for rate-controlling step. ${ }^{26}$ In current study, plot of qt against $\sqrt{ }_{t}$ is linear but it does not pass through origin shown in Fig. 9 Which is indicating that sorption rate is controlled by some other kinetic phenomenon and all of which may be operating at the same time.

Equation of this model is given as;

$$
\mathrm{q}_{\mathrm{t}}=\mathrm{R}_{\mathrm{d}} \mathrm{V}_{\mathrm{t}}
$$

Where, the rate constant of intra-particle diffusion is $\mathrm{R}_{\mathrm{d}}$ which is calculated from the slope of plot of qt against $\sqrt{t}$ and $q_{t}$ is the amount of metal ions sorbed in $\mu \mathrm{g} / \mathrm{g}$ at time $\mathrm{t}$ in $\min ^{-1 / 2}$.

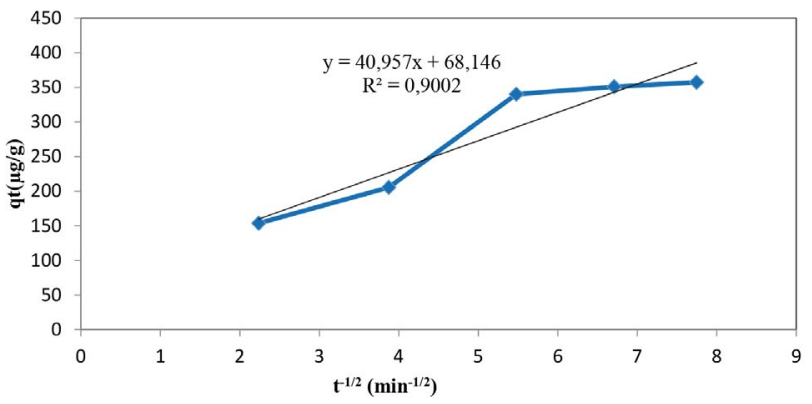

Figure 9. Morris-Weber kinetic model for $\mathrm{Cr}$ (VI) sorption onto isatin based Amberlite XAD-2

\section{7. Sorption Isotherm}

Sorption isotherm play main role to predict the sorbent capacity for removal of a pollutant. The sorption capability of isatin based Amberlite XAD-2 for removal of $\mathrm{Cr}(\mathrm{VI})$ ions has been evaluated by applying Langmuir, Freundlich and D-R isotherms.

\section{7. 1. Langmuir Isotherm}

The Langmuir isotherm is used for the assumption of monolayer surface coverage which shows equal affinity of all binding sites for sorbate molecules and maximum sorption capacity of the sorbent is calculated by using Eq. (5)

$$
\frac{\mathrm{C}_{\mathrm{e}}}{C_{\mathrm{ads}}}=\frac{1}{Q \mathrm{~b}}+\frac{\mathrm{C}_{\mathrm{e}}}{Q}
$$

The plot of $\mathrm{C}_{\mathrm{e}} / \mathrm{C}_{\mathrm{ads}}$ versus $\mathrm{C}_{\mathrm{e}}$ gives $1 / \mathrm{Q}$ and $\mathrm{b}$ as a slope and intercept from which value of $\mathrm{Q}$ can be obtained. In this equation $b$ is a constant related to free energy of sorption. $^{27}$

The non-linear plot of $\mathrm{C}_{\mathrm{e}} / \mathrm{C}_{\text {ads }}$ versus $\mathrm{C}_{\mathrm{e}}$ was obtained in current study, which indicated that experimental data does not follow the Langmuir isotherm Fig. 10. The regression coefficient was also not fitted to experimental data.

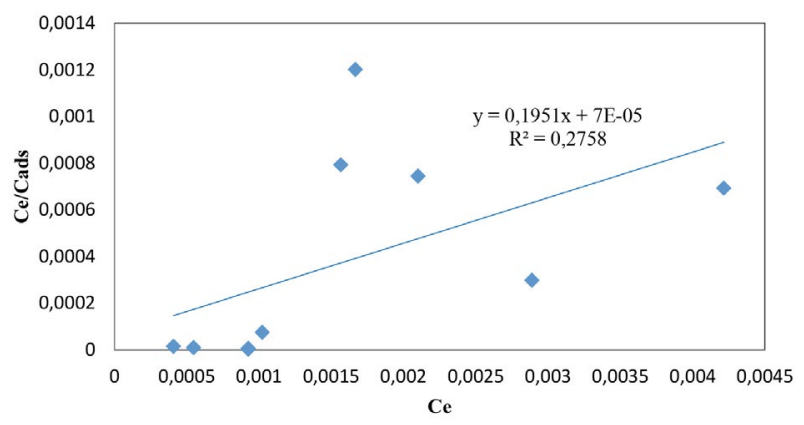

Figure 10. Langmuir kinetic model for $\mathrm{Cr}(\mathrm{VI})$ sorption onto isatin based Amberlite XAD-2

\section{7. 2. Freundlich Isotherm}

The Freundlich isotherm Eq. (VI) is applied to predict the probability of multi-layer surface coverage and it is characterized depend on the non-linear energy distribution of the sorption sites for the same sorbent. ${ }^{28}$ 


$$
\log \mathrm{C}_{\mathrm{ads}}=\log \mathrm{A}+\frac{1}{n} \log \mathrm{C}_{\mathrm{e}}
$$

Where, maximum sorption capacity A and heterogeneity factor $1 / \mathrm{n}$ which are Freundlich constants can be determined from the slope and intercept of plot of $\ln \mathrm{C}_{\mathrm{ads}}$ versus $\ln C_{e}$. In this study the value of $1 / n,<1$, shows that $\mathrm{Cr}(\mathrm{VI})$ is favorably sorbed by the resin at lower equilibrium concentration. ${ }^{29}$ Calculated values are listed in Table 3.

The linear plot of $\ln C_{e}$ versus $\ln C_{a d s}$ and regression coefficient $\mathrm{R}^{2}=0.93$ shown in Fig. 11 has indicated that experimental data gave good fit to Freundlich isotherm.

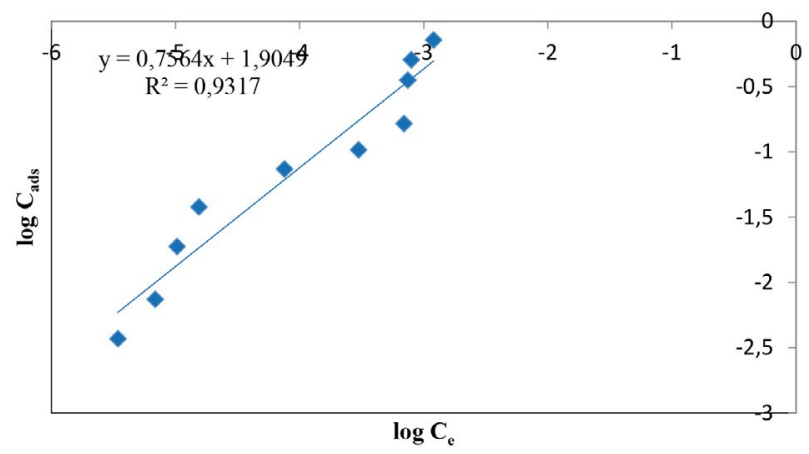

Figure 11. Freundlich isotherm for $\mathrm{Cr}(\mathrm{VI})$ sorption of onto isatin based Amberlite XAD-2

\section{7. 3. Dubinin- Radushkevich Isotherm}

The D-R isotherm was applied to presume the porosity characteristics and the apparent free energy of sorption. The Eq. (7) shows the linearized form of the D-R equation

$$
\ln \mathrm{C}_{\mathrm{ads}}=\ln \mathrm{X}_{\mathrm{m}}-\beta \varepsilon^{2}
$$

Where $\mathrm{C}_{\mathrm{ads}}$ is the amount of $\mathrm{Cr}(\mathrm{VI})$ ions sorbed per unit mass of sorbent, $\mathrm{X}_{\mathrm{m}}$ and $\beta$ are $\mathrm{D}-\mathrm{R}$ isotherm constants, and $\varepsilon$ is a Polanyi potential which is as given in Eq. (8)

$$
\varepsilon=R T \ln \left(1+\frac{1}{C_{\mathrm{e}}}\right)
$$

Where $\mathrm{R}$ is a gas constant in $\mathrm{KJ} / \mathrm{mol}$, $\mathrm{T}$ is the temperature in $\mathrm{K}$ and $\mathrm{C}_{\mathrm{e}}$ is the equilibrium concentration. The linear plot of $\varepsilon^{2}$ versus $\ln C_{\text {ads }}$ shown in Fig. 12 gives $\beta$ and $\ln \mathrm{X}_{\mathrm{m}}$ as slope and intercept, energy $\mathrm{E}$ can be obtained from the value of slope by using Eq. (9). ${ }^{30}$

$$
\mathrm{E}=\frac{1}{\sqrt{ }-2 \beta}
$$

The value of mean free energy $\mathrm{E}(\mathrm{kJ} / \mathrm{mol})$ suggests that sorption mechanism is either chemical ion exchange or physisorption. According to literature if $\mathrm{E}$ value is in the range of $0-8$ then sorption mechanism will be considered as physisorption and the if the value lies in between $8-16$ it will correspond to chemisorptions. ${ }^{31}$

In current study, the value of mean free energy $\mathrm{E}$ is $3.58 \mathrm{KJ} / \mathrm{mol}$ which is calculated from the value of slope given in Table 3 assuming that sorption mechanism of $\mathrm{Cr}$ (VI) onto modified Amberlite XAD-2 follows physisorption.

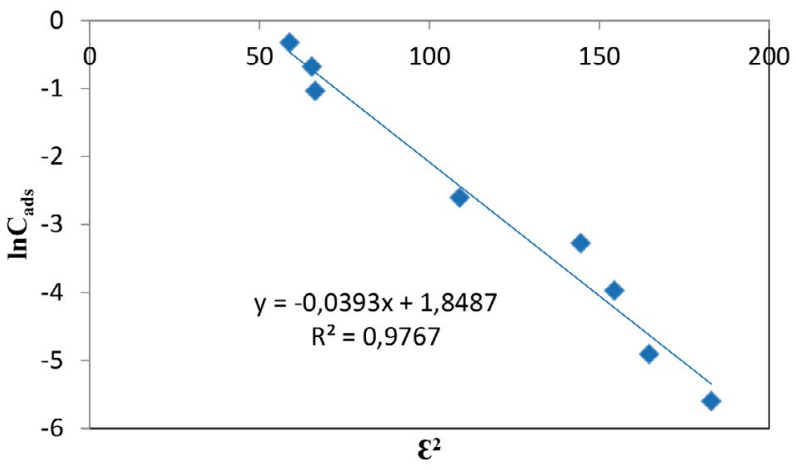

Figure 12. Dubinin-Raushkevich isotherm for $\mathrm{Cr}(\mathrm{VI})$ sorption onto isatin based Amberlite XAD-2 resin

Table 3. Isotherm parameters for $\mathrm{Cr}(\mathrm{VI})$ sorption on Isatin based Amberlite XAD-2 resin

\begin{tabular}{lcc}
\hline Parameters & Freundlich & D-R \\
\hline $\mathrm{A}(\mu \mathrm{g} / \mathrm{g})$ & 6.712 & - \\
$\mathrm{X}_{\mathrm{m}}(\mu \mathrm{g} / \mathrm{g})$ & - & 6.347 \\
$1 / \mathrm{n}$ & 0.756 & - \\
$\mathrm{E}(\mathrm{kJ} / \mathrm{mol})$ & 3.58 & \\
$\beta\left(\mathrm{mol}^{2} \mathrm{KJ}^{-2}\right)$ & - & -0.039 \\
$\mathrm{R}^{2}$ & 0.931 & 0.976 \\
\hline
\end{tabular}

\section{8. Thermodynamics of Sorption}

Sorption of $\mathrm{Cr}(\mathrm{VI})$ onto isatin based Amberlite $\mathrm{XAD}-2$ resin was analyzed at different temperatures between 10 and $50{ }^{\circ} \mathrm{C}$ and maximum sorption was obtained at $10^{\circ} \mathrm{C}$. It was reported that the sorption capacity reduced with increase in temperature suggests that sorption process is exothermic. Temperature reliance of sorption process is connected with different thermodynamic parameters like change in Gibbs free energy $\left(\Delta \mathrm{G}^{\circ}\right)$, entropy $\left(\Delta \mathrm{S}^{\circ}\right)$ and enthalpy $\left(\Delta \mathrm{H}^{\circ}\right)$ were analyzed by Van't Hoff equations which are given as follows

$$
\begin{aligned}
& \Delta G^{\circ}=-R T \ln K_{\mathrm{c}} \\
& \ln \mathrm{K}_{\mathrm{c}}=\frac{\Delta S^{\circ}}{R}-\frac{\Delta H^{\circ}}{R T}
\end{aligned}
$$

Where, $\mathrm{R}$ is the gas constant $(8.314 \mathrm{~J} / \mathrm{molK}), \mathrm{T}$ is absolute temperature $(\mathrm{K})$ and $\mathrm{K}_{\mathrm{c}}$ is the equilibrium constant. The Value of $\mathrm{K}_{\mathrm{c}}$ was obtained from the ratio of amount of $\mathrm{Cr}(\mathrm{VI})$ sorbed onto modified Amberlite XAD- 
2 resin to that of solution phase concentration of $\mathrm{Cr}(\mathrm{VI})$. The values of $\Delta \mathrm{H}^{\circ}, \Delta \mathrm{S}^{\circ}$ and $\Delta \mathrm{G}^{\circ}$ are given in Table 4. The variation in enthalpy and entropy were obtained from slope and intercept of the plot of $\operatorname{lnk}_{\mathrm{c}}$ versus $1 /$ T respectively Fig. 13. ${ }^{32-33}$

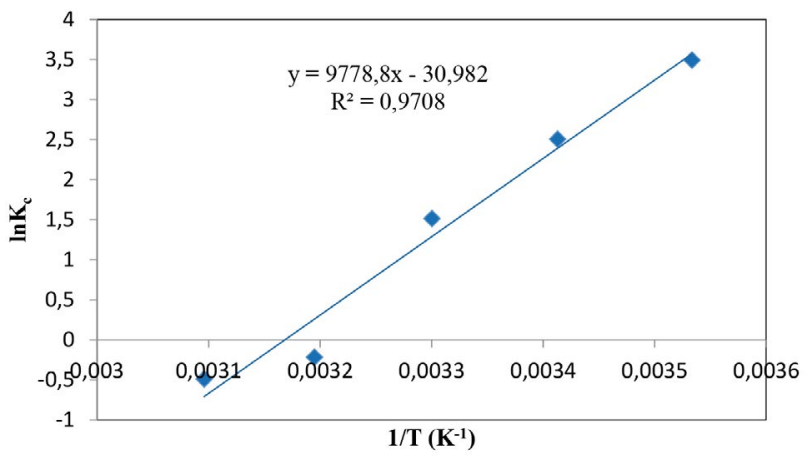

Figure 13. Temperature effect on the sorption of $\mathrm{Cr}(\mathrm{VI})$ ions on Isatin based Amberlite XAD-2

Table 4. Thermodynamic parameters of $\mathrm{Cr}(\mathrm{VI})$ sorption onto isatin based Amberlite XAD-2 resin

\begin{tabular}{cccc}
\hline $\mathbf{T}\left({ }^{\circ} \mathbf{C}\right)$ & $\Delta \mathbf{H}^{\circ}(\mathbf{K J} / \mathbf{m o l})$ & $\Delta \mathbf{S}^{\circ}(\mathbf{J} / \mathbf{m o l K})$ & $\Delta \mathbf{G}^{\circ}(\mathrm{KJ} / \mathbf{m o l})$ \\
\hline 10 & -81.25 & -0.257 & -8.214 \\
20 & & -6.102 & \\
30 & & -3.812 & \\
40 & & 0.565 & \\
50 & & 1.310 & \\
\hline
\end{tabular}

In this study, the negative enthalpy change indicating exothermic nature of the sorption process whereas negative entropy change showed that randomness of $\mathrm{Cr}(\mathrm{VI})$ reduces as it passed from solution to sorbed state. The negative free energy changes from 10 to $30^{\circ} \mathrm{C}$ indicated the spontaneous nature of the process while from 40 to $50{ }^{\circ} \mathrm{C}$ positive value of free energy change was taken as a sign of non-spontaneous sorption process.

\section{9. Interference Study}

Presence of common ions in solution is reported to have effect on removal efficiency, this is may be owing to formation of precipitates or competition for sorption sites. ${ }^{34}$ Therefore effect of different ions on removal efficiency of $\mathrm{Cr}(\mathrm{VI})$ ions onto isatin based Amberlite XAD2 have been examined using optimized conditions. 1:10 concentration ratio of some anions and cations were added with the $\mathrm{Cr}(\mathrm{VI})$ solution. In the presence of sodium nitrate, sodium phosphate, nickel chloride, manganese sulphate, sorption of chromium (VI) was reduced while remaining added electrolytes have no considerable effect on the sorption. The results are shown in the Fig.14.

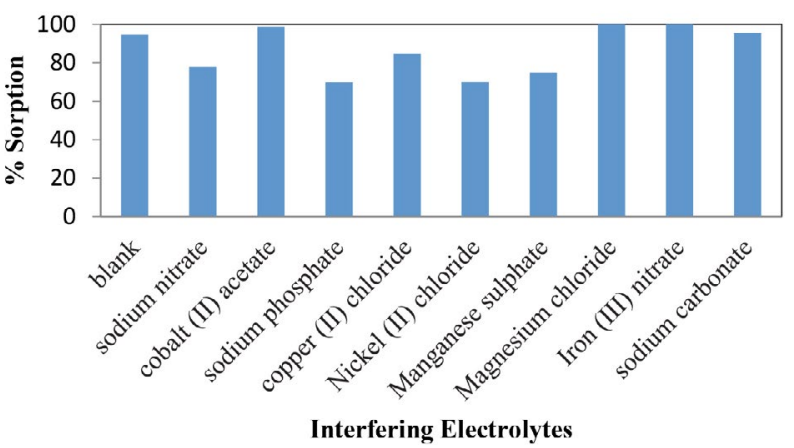

Figure 14. Sorption of $\mathrm{Cr}(\mathrm{VI})$ onto isatin based Amberlite XAD-2 resin in the presence of other electrolytes

Table 5. Interference effect of electrolytes on the $\mathrm{Cr}(\mathrm{VI})$ removal

\begin{tabular}{lc}
\hline Interference Species & \% Sorption \\
\hline Sodium nitrate & $78 \%$ \\
Cobalt (II) acetate & $98 \%$ \\
Sodium phosphate & $70 \%$ \\
Copper (II) chloride & $84 \%$ \\
Nickel (II) chloride & $70 \%$ \\
Manganese sulphate & $75 \%$ \\
Magnesium chloride & $100 \%$ \\
Iron (III) nitrate & $100 \%$ \\
Sodium carbonate & $95 \%$ \\
\hline
\end{tabular}

\section{10. Desorption Study}

It is necessary to explore the removal efficiency of loaded metal from the isatan based Amberlite XAD resin to make certain their long term use for repeated removalrecovery cycles. The regeneration of the modified resin can be used as an indicator to find its potential capability for commercial application.

The metal ions sorption capacity as well as mechanical stability of the modified Amberlite XAD resin was determined by the three consecutive cycles of sorption-desorption experiments. $0.1 \mathrm{M} \mathrm{HNO}_{3}, 0.1 \mathrm{M} \mathrm{NaOH}$ and $0.1 \mathrm{M} \mathrm{HCl}$ solutions were used as desorbing agent.

The $0.1 \mathrm{M} \mathrm{NaOH}$ was found to be effective eluent to desorbed $\mathrm{Cr}(\mathrm{VI})$ from resin. The total \% sorption efficiency was decreased $25 \%$ for at least three cycles. It is revealed from the obtained result that our modified resin has significant potential to sorbed $\mathrm{Cr}(\mathrm{VI})$ species from water after recycling for three times.

\subsection{Applications of Developed Method}

The developed methodology was applied for $\mathrm{Cr}(\mathrm{VI})$ removal from well water, RO plant, ground and tap water samples by spiking known concentration of $\mathrm{Cr}(\mathrm{VI})$ ions through batch technique using optimized conditions. The $\%$ sorption was found to be quantitative as shown in Table 6. 
Table 6. $\mathrm{Cr}(\mathrm{VI})$ removal from water samples

\begin{tabular}{lcc}
\hline Sample & $\begin{array}{c}\text { \% Sorption } \\
\text { (spiked amount 10 } \boldsymbol{\mu g})\end{array}$ & $\begin{array}{c}\text { \% Sorption } \\
\text { (spiked amount 20 } \boldsymbol{\mu g})\end{array}$ \\
\hline Ground water & $95 \%$ & $95 \%$ \\
RO plant & $96 \%$ & $96 \%$ \\
Well water & $5 \%$ & $95 \%$ \\
Tap water & $94 \%$ & $94 \%$ \\
\hline
\end{tabular}

\section{Comparison with Other Sorbents}

The modified resin were compared with the reported sorbent used for the removal of $\mathrm{Cr}$ (VI) species. First of all, the synthetic methodology is very simple and environmental benign. On the other hand, it is clearly seen that the our modified resin have higher surface area with more available binding sites which are capable to remove toxic $\mathrm{Cr}$ (VI) ions efficiently. The experimental values also revealed that our modified resin has more sorption capacity with the previously reported resins. The comparison is summarized in Table 7.

\begin{tabular}{lcc}
\hline Sorbent & $\begin{array}{c}\text { Sorption } \\
\text { Capacity } \\
\mathbf{\mu g} / \mathbf{g}\end{array}$ & Ref \\
\hline $\begin{array}{l}\text { Isatin Functionalized } \\
\text { XAD-2 Resin }\end{array}$ & 7.16 & $\begin{array}{c}\text { This work(Based on } \\
\text { Freundlich isotherm) }\end{array}$ \\
$\begin{array}{l}\text { Modified Silica MCM-41 } \\
\text { Imidazole-4,5-dicarboxylic }\end{array}$ & - & 35 \\
acid Modified XAD & 1.12 & 36 \\
$\begin{array}{l}\text { Xanthine Functionalized } \\
\text { XAD Resin }\end{array}$ & 1.13 & 37 \\
6-Marcaptopurinyl azo & 1.06 & 38 \\
$\begin{array}{l}\text { XAD Resin } \\
\text { Shellac Modified XAD }\end{array}$ & 0.017 & 39 \\
\hline
\end{tabular}

\section{Conclusion}

Isatin based Amberlite XAD-2 was successfully synthesized by green synthesis and sorption capacity of modified resin was examined on highly toxic $\mathrm{Cr}(\mathrm{VI})$ removal from water. The Freundlich and D-R models gave better fit to the isotherm data than Langmuir model. The evaluation of kinetic data indicated pseudo-first-order kinetics followed by sorption process. Among thermodynamic parameters, negative enthalpy change indicating that the sorption process is exothermic in nature whereas negative entropy change showed that randomness of $\mathrm{Cr}(\mathrm{VI})$ reduces as it passed from solution to sorbed state. The validity of the proposed method was checked in spiked real water samples. Furthermore the synthesized resin can be reused for three cycles.

\section{Acknowledgments}

Authors are grateful to Institute of Advance Research Studies in Chemical Sciences, and Institute of Pure and
Applied Geology, University of Sindh, Jamshoro for facilitating this study.

\section{Conflict of Interest}

The authors declare that they have no conflict of interest.

\section{References}

1. S. S. Banerjee, D. H. Chen, J. Hazard. Mater. 2007, 147, 792797. DOI:10.1016/j.jhazmat.2007.01.079

2. Y. T. Zhou, H. L. Nie, C. B. White, Zhi Yan He, L. M. Zhu, J. Colloid Interface Sci. 2009, 330, 29-37.

DOI:10.1016/j.jcis.2008.10.026

3. N. Kannan, M. M. Sundaram, Dyes \& Pigm. 2001, 51, 25-40. DOI:10.1016/S0143-7208(01)00056-0

4. W. Jiang, M. Pelaez, D. D. Dionysiou, M. H. Entezari, D. Tsoutsou, K. O'Shea, Chem. Eng. J. 2013, 222, 527-533.

DOI:10.1016/j.cej.2013.02.049

5. S. Kocaoba, G. Akcin, Talanta, 2002, 57, 23-30. DOI:10.1016/S0039-9140(01)00677-4

6. S. Ertul, M. Bayrakci, M. Yilmaz, J. Hazard. Mater. 2010, 181, 1059-1065. DOI:10.1016/j.jhazmat.2010.05.121

7. N. Goyal, S. C. Jain,S, U. C. Banerjeen, Adv. Environ. Res. 2003, 7, 311-319. DOI:10.1016/S1093-0191(02)00004-7

8. A. M. Yusof, N. A. Malek, J. Hazard. Mater. 2009, 162, 10191024. DOI:10.1016/j.jhazmat.2008.05.134

9. M. I. Qureshi, F. Patel, N. Al-Baghli, B. Abussaud, B. S. Tawabini, T. Laoui, Bioinorg. Chem. Appl. 2017, 2017, 10-16. DOI:10.1155/2017/1624243

10. B. Subramanyam, A. Das, Int. J. Environ. Sci. Tech. 2009, 6, 633-640. DOI:10.1007/BF03326104

11. K. S. Padvamathy, G. Madhu, P. V. Haseena, Procedia Technol. 2016, 24, 585-594.

DOI:10.1016/j.protcy.2016.05.127

12. J. C. Igwe, A. Abia, Afr. J. Biotechnol. 2006, 5, 167-1179.

13. A. O. Dada, A. P. Olalekan, A. M. Olatunya, O. Dada, Langmiur, Freundlich, Temkin and Dubinin-Radushkevich, 2012, J. Appl. Chem. 3, 38-45.

DOI: $10.9790 / 5736-0313845$

14. E. R. Ushakumary., G. Madhu, Int. J. Environ. Waste Manage. 2014, 13, 75-89.

DOI:10.1504/IJEWM.2014.058796

15. C. Song, S. Wu, M. Cheng, P. Tao, M. Shao, and G. Gao, 2013, Sustainability, 6, 86-98. DOI:10.3390/su6010086

16. H. Ye, Z. Yu, Nat. Resour. 2010, 1, 104-109.

17. C. Namasivayam, N. Kanchana, R. T. Yamuna, Waste Manage. 1993, 13, 89-95.

DOI:10.1016/0956-053X(93)90038-X

18. A. Ahmed, J. A. Siddique, M. A. Laskar, R. Kumar, S. H. M. Setapar, A. Khatoon, R. A. Shiekh, 2015, J. Environ. Sci. 31, 104-123. DOI:10.1016/j.jes.2014.12.008

19. M. I. Hoque, D. A. Chowdhury, R. Holze, A. N. Chowdhury, M. S. Azam, J. Environ. Chem. Eng. 2015, 3, 831-842.

DOI:10.1016/j.jece.2015.03.020 
20. A. M. Thakre, V. V. Hiwase, A. B. Kalambe, Arch. Appl. Sci. Res. 2012, 4, 1150-1154.

21. D. L. Pavia, G. M. Lampman, G. S. Kriz. Introduction to spectroscopy, $3^{\text {rd }}$ Ed. Thomson Learning, 2001, Chapter 2, pp. 26.

22. M. K. Rai, G. Shahi, V. Meena, R. Meena, S. Chakraborty, R. S. Singh, B. N, Rai. Resour. Technol. 2016, 2, 563-570.

23. M. P. Leite, L. G. T. Dos Reis, N. F. Robaina, W. F. Pacheco, R. J. Cassella, Chem. Eng. J. 2013, 215, 691-698.

DOI:10.1016/j.cej.2012.10.087

24. M. Ciopec, C. M. Davidescu, A. Negrea, I. Grozav, L. Lupa, P. Negrea, A. Popa, Chem. Eng. Res. \& Des., 2012, 19, 16601670. DOI:10.1016/j.cherd.2012.01.016

25. U. A. Qureshi, A. R. Solangi, S. Q. Memon, S. I. H. Taqvi, N. Memon, Clean (Weinh) 2012, 40, 630-639.

DOI:10.1002/clen.201100287

26. S. M. yakout, E. Elsherif, Carbon-Sci. Tech. 2010, 1, 144-153.

27. V. Srihari, A. Das, Ecotoxicol Environ. Safe. 2008, 71, 274-283. DOI:10.1016/j.ecoenv.2007.08.008

28. S. Q. Memon, M. I. Bhanger, S. M. Hasany, M. Y. Khuhawar, Talanta, 2007, 72, 1738-1745.

DOI:10.1016/j.talanta.2006.12.017

29. S. Q. Memon, M. I. Bhanger, M. Y. Khuhawar, Anal. Bioanal. Chem.ww 2005, 383, 619-624.

DOI:10.1007/s00216-005-3391-1
30. U. A. Qureshi, A. R. Solangi, S. Q. Memon, S. I. H. Taqvi, Arab J. Chem. 2014, 7, 1166-1177.

DOI:10.1016/j.arabjc.2013.08.018

31. A. A. Bhatti, S. Memon, N. Memon, A. A. Bhatti, I. B. Solangi, Arab. J. Chem. 2017, 10, S1111-S1118.

DOI:10.1016/j.arabjc.2013.01.020

32. S. O. Owalude, A. C. Tella. Beni-Suef, Univ. J. Appl. Sci. 2016, 5, 377-388. DOI:10.1016/j.bjbas.2016.11.005

33. Z. Yu, T. Qi, J. Qu, L. Wang, J. Chu, J. Hazard. Mater. 2009, 167, 406-412. DOI:10.1016/j.jhazmat.2008.12.140

34. J. R. Memon, S. Q. Memon, M. I. Bhanger, M. Y. Khuhawer, G. C. Allen, G. Z. Memon, A. G. Pathan, Eur. Polym. J. 2008, 44, 1501-1511. DOI:10.1016/j.eurpolymj.2008.02.018

35. M. R. Ganjali, L. H. Babaei, A. Badiei, K. Saberian, S. B. Abureihan, G. M. Ziarani, M. Salavati-Niasari, Quim. Nova, 2006, 29, 440-443. DOI:10.1590/S0100-40422006000300007

36. D. Banerjee, B. C. Mondal, A. K. Das, J. Indian Chem. Soc., 2003, 80, 769-772.

37. D. D. Banerjee, A. K. Das, J. Indian Chem. Soc., 2006, 83, 479-484.

38. B. C. Mondal, A. K. Das, Bull. Chem. Soc. Jpn., 2003, 76, 111114. DOI:10.1246/bcsj.76.111

39. Y. Sibel, A. Resat, Int. J. Environ. Anal. Chem., 2006, 86, 915929.

\section{Povzetek}

Amberlit XAD-2 smo funkcionalizirali z izatinom preko $-\mathrm{C}=\mathrm{N}$ - ročic $\mathrm{z}$ uporabo okolju prijaznega postopka. Tako pripravljenemu nosilcu smo določili adsorpcijsko kapaciteto toksičnih $\mathrm{Cr}$ (VI) ionov s pomočjo spektrofotometra. Optimizirali smo pH vrednost, volumen, količino adsorbenta, začetno koncentracijo $\mathrm{Cr}$ (VI) ionov in čas mešanja. Izkazalo se je, da adsorpcijske podatke bolje opišemo z Freundlichovo in Dubinin- Radushkevichovo kot pa z Langmuirjevo izotermo. Ovrednoteni so bili termodinamski parametri, kinetični podatki so pokazali, da hitrost adsorpcije lahko opišemo z modelom pseudo-prvega reda. Maksimalni izkoristek je bil dosežen pri $10 \mathrm{ml}$ v $0.1 \mathrm{M} \mathrm{NaOH}$. Ustreznost metode smo preverili z metodo standardnega dodatka. Rezultati so pokazali, da lahko z razvito metodo učinkovito odstranjujemo Cr (VI) ione iz vode in lahko adsorbent uporabimo vsaj trikrat.

Except when otherwise noted, articles in this journal are published under the terms and conditions of the Creative Commons Attribution 4.0 International License 